MATEC Web of Conferences 49, 07002 (2016)

DOI: $10.1051 /$ matecconf/20164907002

(C) Owned by the authors, published by EDP Sciences, 2016

\title{
Molecular Studies on Preproinsulin Gene
}

\author{
Sarah Sabir' a , Hooria Younas \\ Kinnaird College for Women 93-Jail Road, Lahore Pakistan
}

\begin{abstract}
Insulin plays an important role in maintaining the blood glucose level of the body. The $\beta$-cells of pancreas produce insulin in the form of precursor that is preproinsulin. The gene of preproinsulin provides an interesting system for addressing question related to molecular evolution. Recombinant DNA technology has made it possible to isolate and sequence the chromosomal genes coding for unique protein products. Although preproinsulin of various organism has been isolated and cloned, but there is no report from buffalo (Bubalus bubalis) that is our major livestock. The genomic DNA of buffalo was isolated using Laura-Lee-Boodram method. The part of preproinsulin gene (596bp and 520bp) using BPPI-UPS and bpiful_F as forward and BC1-C as reverse primer was amplified. Cloning of amplified fragments of gene were performed in pCR 2.1 vector. Positive clones were screened on the basis of blue white selection. The band obtained on 596bp and 520bp after colony PCR confirmed the successful cloning of preproinsulin gene in $\mathrm{pCR} 2.1$ vector.
\end{abstract}

\section{Introduction}

Diabetes mellitus is a metabolic disease in which blood glucose level of the person is high because the body does not produce insulin or the cells do not respond to the insulin which is produced in the body [1]. The main role of insulin in liver, muscles and fat tissues is to control the sugar level, proteins and fat metabolism. The major role of insulin is to regulate blood glucose level, to promote protein synthesis and prevent its decomposition [2]. High blood glucose level stimulates the $\beta$-cells of pancreas to release insulin, which allows the glucose to enter the body's cell and it is used as a fuel for energy. It maintains the blood sugar level in the range of $80-120 \mathrm{mg} / \mathrm{dl}$. If the glucose level goes low that another hormone glucagon is produced by the alpha cells of pancreas in the opposite direction as compared to insulin. The function of glucagon is to release the stored glucose in the bloodstream [2]. Insulin is a small protein of 51 amino acids and molecular weight of about $6000 \mathrm{Da}$. It is composed of two polypeptide chains; chain A has 21 amino acids and chain $\mathrm{B}$ has 30 amino acids [3]. Insulin is synthesized as a single precursor molecule, preproinsulin, which is posttranslationally modified to give the mature hormone [4]. Beta cells release insulin in response to change in glucose level. Type 2 glucose transporters are responsible for the entry of glucose in the cells. The glucokinase modify the glucose molecules by adding phosphate group so that they are trapped in beta cells and is mobilized to ATP. As the level of ATP rises the potassium gated channels close up, preventing potassium ions from being shunted across the cell membrane. The rise in positive charge due to potassium ions causes depolarization, this causes the calcium ion channels to open and transport calcium ions in the cells. The increase in calcium ions trigger the export of insulin storing granules by exocytosis and this results in the transport of insulin out of the cells in the bloodstream[5]. When insulin reaches the liver cells it bind to its receptors present on the cell member of the liver, as it binds a number of different chemical reactions are affected in the liver. Firstly it causes the liver cells to increase the breakdown of glucose and secondly it causes the glucose to be converted to glycogen and stored in the liver cells [5]. The genes and mRNAs that encode preproinsulin have been cloned from a variety of species, mouse [6], human[7], guinea pig[8], chicken [9], dog [10], birds [11], bovine [12] and buffalo proinsulin mRNA (Accession No AB234871.1) [13] have been sequenced. So, to fill the gap preproinsulin from buffalo (Bubalus bubalis).

\section{Materials and methods}

Blood sample of buffalo (Bubalus bubalis) was collected from slaughter house in a vial containing $10 \mu \mathrm{l}$ of EDTA.

Genomic DNA wad isolated from this sample by Laura-Lee-Boodram method [14]. The quality and quantity of genomic DNA was analyzed on $1 \%$ agarose gel.

In the present study following primer sets were used to amplify the part of preproinsulin gene.

BPPI-UPS(Forward):

GCTCCTGGAGGCCCTGATGACGGGCCAG

Bpiful F(Forward):

TCATATĞGACCGGCTGCATTCGAGGCTGCCAG.

\footnotetext{
${ }^{\mathrm{a}}$ Corresponding author: sarahrehmat $@$ gmail.com
} 
BC1-C(Reverse):

GCCGCGCTTCTGCGGGGGGCCCTCCACCTCCCGG CGGGC.

Bpi-R(Reverse):

\section{GTTTAAGCTTGTCGGGGGCAGGCCTAGTTACAG}

All the primers were dissolved in autoclaved water to make their final concentration $100 \mathrm{pmol} / \mu \mathrm{l}$. The aliquots of these primers were stored at $-20^{\circ} \mathrm{C}$.

Four PCR reaction mixtures, each of $50 \mu \mathrm{l}$ were prepared as mentioned in table 3.8. The reaction mixtures were incubated in thermal cycler at $95^{\circ} \mathrm{C}$ for 5 minutes and were then amplified for 35 cycles, each consist of 45 seconds at $95^{\circ} \mathrm{C}, 0: 30$ seconds at $55^{\circ} \mathrm{C}$ for annealing and $1: 10$ at $72^{\circ} \mathrm{C}$. The reaction mixtures were incubated of 5 minutes at $72^{\circ} \mathrm{C}$ for complete extension. PCR product was analyzed on $1 \%$ Agarose gel electrophoresis as described previously.

PCR product was analyzed on 1\% Agarose gel electrophoresis

Products and the band of PCR was excised and DNA was extracted from gel using commercially available "PureLink ${ }^{\circledR}$ Quick Gel extraction Kit" Invitrogen Company using the protocol provided with kit.

The purified PCR product was ligated into a cloning vector, pCR ${ }^{2} 2.1$ vector $(20 \mathrm{ng} / \mu \mathrm{l})$ using "The Quality TA cloning ${ }^{\circledR}$ Kit”. $20 \mu$ l of ligation mixture for each PCR product was prepared in Eppendorf tubes and it was incubated at $14^{\circ} \mathrm{C}$ in cooling incubator for overnight as mentioned in Table 1.

Table 1. Preparation of Ligation mixture for T/A ligation of preproinsulin gene.

\begin{tabular}{|c|c|c|}
\hline Reagents & $\begin{array}{l}\text { PCR Product (BPPI- } \\
\text { UPS/BC1-C) }\end{array}$ & $\begin{array}{c}\text { PCR Product } \\
\text { (bpiful_F/BC1-C) }\end{array}$ \\
\hline $\begin{array}{l}\text { 5X ligation } \\
\text { buffer }\end{array}$ & $4 \mu 1$ & $4 \mu 1$ \\
\hline $\begin{array}{l}\text { PCR } \\
\text { product }\end{array}$ & $12 \mu 1$ & $12 \mu 1$ \\
\hline $\begin{array}{c}\text { T4 DNA } \\
\text { ligase } \\
5 \mathrm{U} / \mu 1 \\
\end{array}$ & $20 \mu 1$ & $20 \mu \mathrm{l}$ \\
\hline Total & $20 \mu 1$ & $20 \mu \mathrm{l}$ \\
\hline
\end{tabular}

$200 \mu 1$ of competent cells of E.Coli DH5 $\alpha$ were added in each sample of $20 \mu \mathrm{l}$ ligation mixture. Negative control contains only $200 \mu \mathrm{l}$ competent cells and Positive control contains $200 \mu \mathrm{l}$ of competent cells and Bpi/pTZ57R/T recombinant construct. Samples were mixed gently and placed on ice for 40 minutes. Screening of positive clones was performed by blue white selection method [15] using LB agar plates containing IPTG, X-Gal and ampicillin.

The ligation of BPPI-UPS and bpiful_F gene into pCR ${ }^{\circledR} 2.1$ vector was confirmed by colony PCR. Colony PCR reaction mixture was prepared in PCR tubes, each $25 \mu 1$, as mentioned in table 1 . Five PCR reaction mixtures, each of $50 \mu \mathrm{l}$ were prepared. The reaction mixtures were incubated in thermal cycler at $95^{\circ} \mathrm{C}$ for 5 minutes and were then amplified for 35 cycles, each consist of 45 seconds at $95^{\circ} \mathrm{C}, 0: 30$ seconds at $55^{\circ} \mathrm{C}$ for annealing and $1: 10$ at $72^{\circ} \mathrm{C}$. The reaction mixtures were incubated of 5 minutes at $72^{\circ} \mathrm{C}$ for complete extension. PCR product was analyzed on $1 \%$ Agarose gel electrophoresis as described

\section{Results and discussions}

In eukaryotes insulin is synthesized in the beta cells of pancreas in the form of its precursor, preproinsulin. The preregion of the precursor serves as the hydrophobic signal for the transport of the chain through the membrane of endoplasmic reticulum where the signal sequence is cleaved. Then proinsulin attains its secondary structure and disulfide bond formation takes place and finally converted to insulin. The purpose of the study was to clone the preproinsulin gene of buffalo to highlight the evolutionary aspect if insulin and the species to species variation at the DNA level as well as at protein level.

In this study, Genomic DNA was isolated from buffalo blood by Laura-Lee-Boodram method [14]. Gel electrophoresis was performed to determine the quality and quantity of the DNA extracted using Gel documentation system. The gel (Figure 1) showed bands of DNA. Genomic DNA in the wells and $23 \mathrm{~kb}$ band of smallest fragment of genomic DNA showed good isolation of genomic DNA. There is no smear of degrade DNA in the gel that shows that the quality of DNA is good and it can be used for further analysis.

There are certain difficulties in isolation of genomic DNA. The $\mathrm{pH}$ of buffer A and B should be set otherwise it will cause problem in isolation. After centrifugation supernatant should be discarded carefully so that pellet is not dislodged. Heating process should also be done carefully to inactivate the nuclease if this step is not done carefully the genomic DNA will be cleaved by the nucleases.

Cow and buffalo are closely related species, so primers were designed from the cow sequence (Accession No. EU518675.1) using a software. In case of cow preproinsulin gene there are three exons and two introns. . Four primers were designed to carry out this study. BPPI-UPS (forward primer) was designed from the upstream region of the preproinsulin gene, it was designed to study the promoter region of the preproinsulin gene. Reverse primer Bpi-R was designed near the stop codon so that whole gene can be amplified. The expected fragment size obtained after amplification with BPPI-UPS and Bpi-R is 1213bp. The fragment amplified from these primers contains three exons two introns start codon and stop codon. There was a possibility that there is a difference in cow and buffalo promoter region so another primer bpiful_F was designed from the first exon of the cow preproinsulin gene. The excepted product size is $1137 \mathrm{bp}$ using bpiful_F and Bpi$\mathrm{R}$ as forward and reverse primers respectively. Since there was difficulty in amplifying the fragment larger than $1 \mathrm{~kb}$, so another reverse primer $\mathrm{BC} 1-\mathrm{C}$ was designed from the middle region of the gene sequence. Expected size of fragment amplified with BPPI-UPS and BC1-C is 596bp and with bpiful_F and BC1-C is $520 \mathrm{bp}$. 


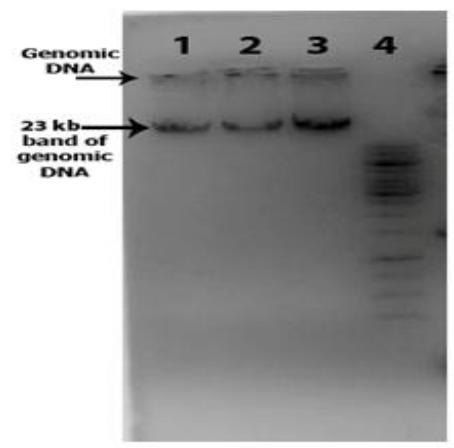

Figure 1. Isolation of genomic DNA.

Lane 1: Buffalo Genomic DNA

Lane 2: Buffalo Genomic DNA

Lane 3: Buffalo Genomic DNA

Lane 4: DNA Ladder

The amplification of preproinsulin gene was a difficult task and many attempts were made to amplify the whole gene of preproinsulin using BPPI-UPS and Bpi-R and bpiful $F$ and Bpi-R, by varying different conditions of $\mathrm{PCR}$ such as annealing temperature, concentration of $\mathrm{MgCl}_{2}$ and the amount of DNA template

Magnesium chloride is used as a co factor for the thermostable Taq DNA polymerase. It also stabilizes the double stranded DNA and increases the Tm. Concentration of $\mathrm{MgCl}_{2}$ is important in controlling the specificity of the reaction. Too low $\mathrm{MgCl}_{2}$ concentration results in low yield of PCR product and too high $\mathrm{MgCl}_{2}$ concentration results in non- specific amplifications. $\mathrm{MgCl}_{2}$ concentration should be used in range of $1 \mathrm{mM}$ $4 \mathrm{mM}$. That is why different concentration of $\mathrm{MgCl}_{2}$ is used in this study.

Due to larger size fragment of $1213 \mathrm{bp}$ there was difficulty in amplification of full preproinsulin gene. So four reaction mixtures were prepared in which $\mathrm{BC} 1-\mathrm{C}$ primer was designed from the middle of the gene sequence, it was used as reverse primer in combination with two forward primers BPPI-UPS and bpiful_F. DNA band at 520bp was observed in lane 1 and lane 2 , and $596 \mathrm{bp}$ of DNA band was observed in lane 4 and lane 5 on $1 \%$ agarose gel.

DNA bands of amplified preproinsulin 596bp (BPPIUPS/BC1-C) and 520bp (bpiful_F/BC1-C) were cut from gel and gene clean was done, as described previously. The gene was ligated into a cloning vector, $\mathrm{pCR} \AA 2.1$ vector $(20 \mathrm{ng} / \mu \mathrm{l})$ using "The Quality TA cloning ${ }^{\circledR}$ Kit”.

Cloning of the PCR product in the vector was done by T/A cloning. When PCR product is amplified using Taq polymerase then it is capable of adding adenosine triphosphate residue to the 3' ends of the double stranded PCR product. Vector is digested with Eco32I restriction enzyme so that the amplified PCR product is cloned in a linearized vector with complementary 3'T overhangs. PCR product with A overhangs is mixed with the vector in high proportion. The complementary $\mathrm{T}$ overhangs of a vector and the A overhang of PCR product hybridizes and the nick is sealed by DNA ligase [15].
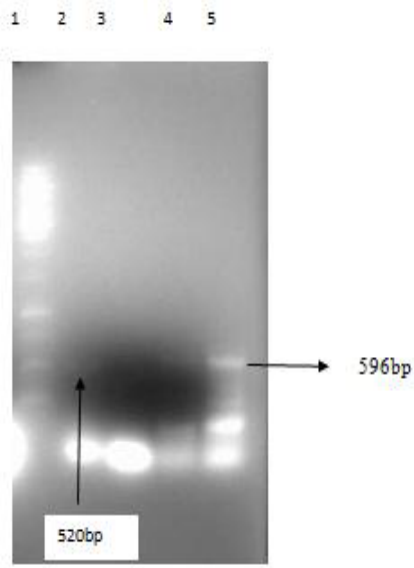

Figure 2. Isolation of PCR amplification of buffalo preproinsulin gene using BPPI-UPS and bpiful_F as forward and $\mathrm{BC} 1-\mathrm{C}$ as reverse primer.

Lane 1: DNA Ladder

Lane 2: PCR amplification of buffalo preproinsulin gene using bpiful_F and $\mathrm{BC} 1-\mathrm{C}, 1.5 \mathrm{mM} \mathrm{MgCl} 2$

Lane 3: PCR amplification of buffalo preproinsulin gene using bpiful_F and BC1-C, $2 \mathrm{mM} \mathrm{MgCl} 2$

Lane 4: PCR amplification of buffalo preproinsulin gene using BPPI-UPS and $\mathrm{BC} 1-\mathrm{C}, 1.5 \mathrm{mM} \mathrm{MgCl} 2$

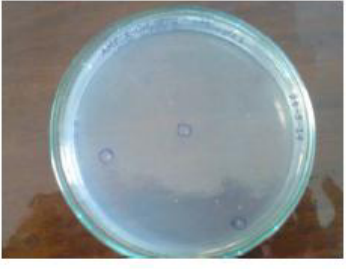

(a)

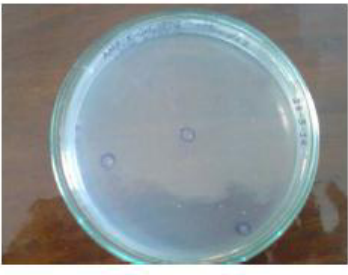

(b)
Figure 3.

(a) White colonies of preproinsulin gene amplified by BPPI-UPS and BC1-C

(b) White colonies of preproinsulin gene amplified by bpiful_F and BC1-C

The pCR 2.1 vector contains a fragment of a gene called $L a c Z$. $L a c Z$ gene codes for the production of an enzyme $\beta$-galactosidase. Normally $\beta$-galactosidase metabolizes galactose into lactose and glucose. $\mathrm{X}-\mathrm{Gal}$ is a substrate for galactose, so $\beta$-galactosidase converts X-Gal, a colorless modified galactose sugar, into a blue colored product. Within the $L a c Z \alpha$ gene there is a multiple cloning site (MCS) where the PCR product can be cloned. The multiple cloning site (MCS) can be cut with the help of restriction enzyme and the PCR product can be inserted within the $L a c Z \alpha$ gene, this disrupts the function of $L a c Z$ gene hence no $\alpha$-peptide is produced. As a result no active $\beta$-galactosidase can be produced [16] that cannot convert the $\mathrm{x}$-gal into a blue colored product so white colonies are formed. But if foreign DNA is not ligated in the vector then the enzyme is fully functional and gives rise to bright blue colored colonies [15].

The cloning of preproinsulin gene in pCR 2.1 vector was confirmed by colony PCR using gene specific primers. In colony PCR white bacterial colonies were used as template instead of buffalo genomic DNA. White 
colonies were picked and mixed with PCR reaction and PCR was run under same conditions.

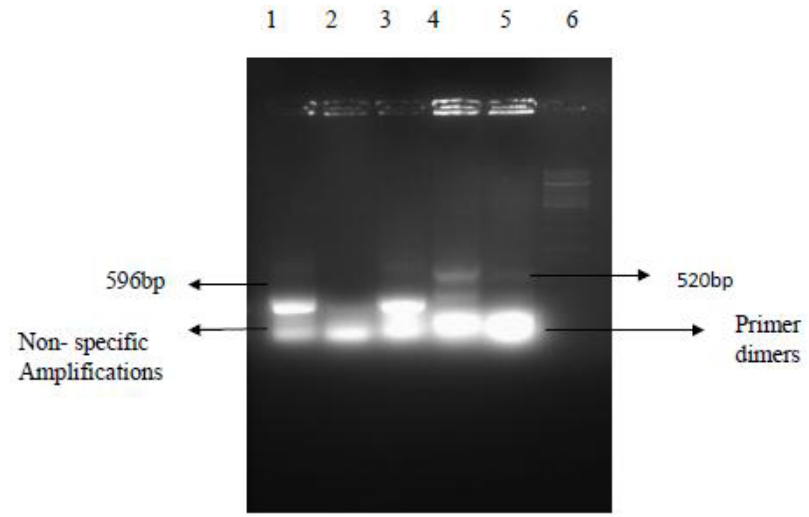

Figure 4. Colony PCR

Lane1: Ampification of BPPI-UPS/BC1-C white colony with BPPI-UPS and BC1-C

Lane 2: Ampification of BPPI-UPS/BC1-C white colony with BPPI-UPS and BC1-C

Lane 3: Ampification of BPPI-UPS/BC1-C white colony with BPPI-UPS and BC1-C

Lane 4: Amplifiaction of bpiful_F/BC1-C white colony with bpiful $\mathrm{F}$ and $\mathrm{BC} 1-\mathrm{C}$.

Lane 5: Amplifiaction of bpiful_F/BC1-C white colony with bpiful_F and BC1-C.

Lane 6: DNA Ladder

At denaturation step the cells were lysed at $94^{\circ} \mathrm{C}$ and the recombinant vector was used as template. If the vector contains the insert the primer binds and amplifies it. The presence of 596bp band confirmed that pCR 2.1 vector contained preproinsulin gene amplified by BPPIUPS and BC1-C. Band at 520bp confirmed that pCR 2.1 vector contains part of preproinsulin gene amplified by bpiful_F and BC1-C primers.

\section{Conclusion}

Amplification of parts of preproinsulin gene, 596 and 520 $\mathrm{bp}$, was done successfully from buffalo genomic DNA using specific forward and reverse primers which were then successfully cloned in vector pCR 2.1. The cloning was confirmed by colony PCR

\section{Recommendation}

Sequencing of the parts of preproinsulin gene should be done and comparison of the sequence with other organism should be studied to find out evolutionary aspects.

\section{References}

1. K. G. M. M. Alberti, P. Z. Zimmet, Diabetes Medicine, 15, 539-553 (1998)

2. DF. Steiner, D. Cunningham, L. Spigelman, B. Alen, AAAS, 153, 697-700 (1969)

3. MJ. Blundel, T. Dodson, E. G. Dodson, M. Vijayan, E. Baker,M. Harding, B. Rimmer, Nature, 224-491 (1969)

4. DF. Steiner, Harvey Lecture, 78, 191-228 (1983)

5. CR. Kahn, MF. White, JCI, 82, 4, 1151-1156 (1988)

6. BM. Wentworth, IM. Schaefer, L. VillaKomaroff, JM. Chirgwin, J. Mol. Evol, 23, 305-12 (1986)

7. SA. Nang, J Biosci 6,739-55, (1984)

8. SJ. Chan, V. Eposkopou, S. Zeitlin, SK Karathanasis, A. Mackrell, DF. Steiner, Proc Natl Acad Sci U.S.A, 81, 5046-50 (1984)

9. F. Perler, A. Efstratiadis, P. Lomecdico, W. Gilbert, R. Koldner, J. Dodgon, Cell, 20, 555-66 (1890)

10. S. Kwok, S. Chan. DF. Steiner, J Biol Chem, 258, 2357-63 (1983)

11. J. Simon, S. Laurent, G. Grolleau, P. Thoraval, D. Soubieux, D. Rasschaert, Mol Phylogenet Evo, 30, 755-66 (2004)

12. PT. Lomedico, S. Chan, DF. Steiner, J Biol Chem, 252, 7971-8 (1977)

13. H. Younas, Studies On Recombinant Buffalo (Bubalus Bubalis) Proinsulin And Its Derivatives. PhD thesis, (2009)

14. TL. Kendall, DJ Byerley, R. Dean, Anal Biochem, 195, 74-6 (1991)

15. D. Chaffin, C. Rubens, Gene, 219, 91-9 (1998)

16. MY. Zhau, Curr Issues Intest Microbiol, 2, 1-8 (2000) 